\title{
Powder agglomeration during the spray-drying process: measurements of air properties
}

\author{
Alessandro GiAnFrancesco*, Christelle TURChIUli, Elisabeth DuMOUlin \\ UMR GenIAl 1145, AgroParisTech-Massy, 1 avenue des Olympiades, 91744 Massy Cedex, France
}

\begin{abstract}
Instant food powders are usually produced by spray drying of formulated liquid and powder agglomeration, either into the drying chamber or in an external fluid bed. During spray drying, according to the liquid composition, the viscosity of the initial liquid drops increases more or less rapidly, until the drop surface reaches a rubbery state considered as sticky, before further drying. This sticky property may be used to produce agglomerates inside the chamber by adding dry solid particles, as fines. The present study deals with a methodology to identify regions where the drying drops are sticky in relation to drying conditions (inlet air temperature $144-159-174{ }^{\circ} \mathrm{C}$, liquid flow rate 15 to $75 \mathrm{~mL} \cdot \mathrm{min}^{-1}$ ), using a co-current pilot spray dryer with rotary atomizer. Assuming that drying air properties' (temperature and humidity) evolution is representative of drop drying (drying rate, amount of evaporated water), we realized a map of temperatures and relative humidity for drying air inside the drying chamber. Trials were performed with water (feasibility) and a maltodextrin aqueous solution ( $40 \% \mathrm{w} / \mathrm{w}, \mathrm{DE} 12)$ as a model product with sticky properties during drying. The results showed that drying behavior was different for water and aqueous maltodextrin solution. For both, in the tested conditions, the percentage of evaporated water was found to vary from 57 to $89 \%$ in the top part of the chamber, close to the atomizer. That represents a possible region where dry fines could be introduced for agglomeration.
\end{abstract}

spray drying / agglomeration / stickiness

\begin{abstract}
摘要 - 喷雾干燥过程中乳粉的凝结: 空气性质的测定。在喷雾干燥生产速溶配方食品时, 在干燥室内或在流化床外部容易发生干粉的凝结。在喷雾干燥过程中, 根据液体的组成, 在 进一步干燥之前, 初始液滴的黏度会或多或少的增加, 直到液滴表面达到胶状, 也就是粘稠状 态。利用这种粘稠特性可以通过在干燥室中加入干燥的固体颗粒, 也就是纯的固体微粒来生 产凝聚物。本研究以带有旋转式喷雾机的顺流喷雾干燥器 (中试规模) 为研究对象, 确定了 干燥液滴与干燥条件之间相对应的秥度区域 (内部空气的温度在 $144-159-174{ }^{\circ} \mathrm{C}$, 液体的流 速在 $15 \sim 75 \mathrm{~mL} \cdot \mathrm{min}^{-1}$ )。假设干燥空气性质 (温度和湿度) 的变化代表了液滴的干燥 (干燥 速率, 水分的蒸发量), 就可以获得在干燥室内部干燥空气的温度和相对湿度的关系图。以水 和糊精水溶液 ( $40 \% \mathrm{w} / \mathrm{w}, \mathrm{DE} 12)$ 为模型研究了干燥过程中的黏度特性。试验结果表明, 水和 糊精水溶液的干燥行为不同。在试验条件下, 两种溶液在干燥室顶部, 接近喷雾器部分的水 分蒸发量在 $57 \%$ 89\%, 这个数据表明可以在这个区域内引入干燥的固体微粒使得被干燥 物质凝结。
\end{abstract}

喷雾干燥 / 凝结 / 黏性

\footnotetext{
* Corresponding author (通讯作者): alessandro.gianfrancesco@ agroparistech.fr
} 
Résumé - Agglomération de poudres au cours du processus de séchage par pulvérisation : mesure des propriétés de l'air. Les poudres alimentaires instantanées sont habituellement produites par séchage par pulvérisation d'une solution formulée, suivi d'une étape d'agglomération, soit dans la chambre de séchage soit dans un lit fluidisé externe. Au cours du séchage, selon la composition du liquide, la viscosité des gouttes liquides augmente plus ou moins rapidement jusqu'à ce que la surface de la goutte devienne collante, avant séchage ultérieur. Cette propriété collante peut être exploitée pour produire des agglomérats dans la chambre par introduction de particules solides sèches, les fines. Cette étude cherche à établir une méthodologie pour identifier des zones où les gouttes qui sèchent deviennent collantes en fonction des paramètres de séchage (température d'entrée d'air $144-159-174{ }^{\circ} \mathrm{C}$, débit liquide de 15 à $75 \mathrm{~mL} \cdot \mathrm{min}^{-1}$ ), en utilisant un séchoir pilote co-courant équipé avec une turbine de pulvérisation. En supposant que l'évolution des propriétés de l'air (température et humidité) au cours du séchage soit représentative du séchage des gouttes (vitesse de séchage, quantité d'eau évaporée), des cartographies des températures et des humidités relatives de l'air dans la chambre de séchage ont été réalisées. Des essais ont été effectués avec pulvérisation d'eau (faisabilité), puis d'une solution de maltodextrine (40\% w/w, DE12) comme produit modèle pouvant avoir un comportement collant au cours du séchage. Les résultats ont montré que le comportement au séchage est différent pour l'eau et pour la solution de maltodextrine. Dans les deux cas, pour les conditions testées, le pourcentage d'eau évaporée varie entre 57 et $89 \%$ dans la partie haute de la chambre, près du pulvérisateur. Cela représente une zone possible où des fines sèches peuvent être introduites dans un but d'agglomération.

\section{séchage par pulvérisation / agglomération / collage}

\section{INTRODUCTION}

The spray-drying process is widely used in the food industry to produce dry powders. The preparation of instant food powders, such as milk, soups, juices and coffee, needs a further step of agglomeration after spray drying. This operation is used to get larger particles (from 50-80 $\mu \mathrm{m}$ to $250-500 \mu \mathrm{m})$ with a narrower size distribution in order to improve flowability; and to modify particle structure (porosity) to obtain good instant properties (wettability, dispersability and solubility).

In industrial practice, agglomeration of spray-dried powders is performed either outside the drying chamber in a fluid bed where the particle surface is wetted with sprayed water (or another binder solution), or by recycling dry fines (particles of a diameter smaller than $100 \mu \mathrm{m}$ ) into the drying chamber. In this last case, dry fines are usually introduced close to the atomizer for a better control of the drying process. Other choices for recycling of fines, leading to controlled agglomeration, might be possible by taking into account the involved mechanisms [12].
During spray drying, liquid droplets in contact with hot air are dried quickly ( $\sim 10 \mathrm{~s})$. Water evaporates from the surface and the viscosity of the drop surface increases progressively and reaches a critical value $\left(10^{7} \mathrm{~Pa} \cdot \mathrm{s},[14]\right)$ at which the particle surface is in a rubbery state that is considered as sticky. Surface stickiness depends on surface temperature, water content and composition (i.e. carbohydrates and fats). When the surface reaches the sticky state, collisions with other particles (sticky or dry) could lead to agglomeration, depending on velocity, force, angle and time of contact between particles $[5,11]$.

Several techniques have been developed to measure sticky behavior of food substances [2]. All these techniques provide a stickiness curve, in which the sticky temperature, $T_{s}$, is expressed as a function of the particle moisture content. An indirect approach correlates the sticky temperature, $\mathrm{T}_{\mathrm{s}}$, to the glass transition temperature, $\mathrm{T}_{\mathrm{g}}$, of the substance; $T_{s}$ is 10 to 30 degrees higher than $\mathrm{T}_{\mathrm{g}}[7,13]$. In static methods, measurements of $\mathrm{T}_{\mathrm{s}}$ are based on dry powder property changes due to sticking, such as resistance to stirring (propeller-driven 


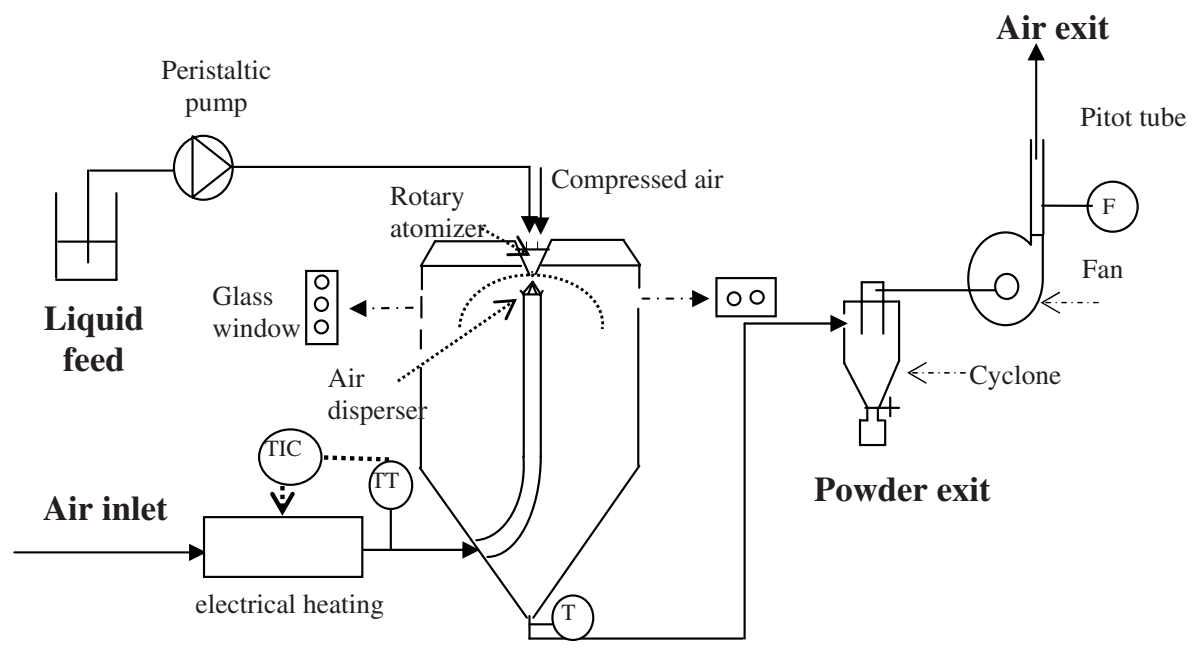

humid air + dry product exit

Figure 1. Scheme of the NIRO Minor Lab pilot spray dryer.

methods $[4,6,8,10]$ ), adhesion (ampule method [15]) or surface optical properties [9]. Other techniques generate powder flow in a humidified air stream within a fluidization cell [3] or in a cyclone [1]. An "in-situ" test uses the development of adhesiveness and cohesiveness of one drop during drying [16].

During drying, heat and mass transfers occur between air and drops/particles, and consequently air temperature decreases and its humidity increases. As it is difficult to follow the changes in the drop surface properties during spray drying, we assumed that the flows of air and particles are associated and that evolution of drying air properties is representative of drop drying, especially in a co-current single-step spray dryer. Air properties can be measured inside the chamber to estimate the particle drying rate, the amount of water evaporated and the maximal product temperature at different levels in the chamber [17].

The objectives of this work are first, to test the feasibilities of air properties measurements in a pilot spray dryer and to use them to identify operating conditions for which particles might be sticky. Afterwards, the sticky conditions will be exploited to perform controlled agglomeration with other solid particles.

\section{MATERIALS AND METHODS}

Trials were performed using a cocurrent pilot spray dryer, Niro Minor Lab (Copenhagen, Denmark; 1 to $3 \mathrm{~kg} \cdot \mathrm{h}^{-1}$ evaporative capacity), equipped with a rotary atomizer (Fig. 1). The drying chamber $(\mathrm{d}=0.8 \mathrm{~m}, \mathrm{~h}=1.2 \mathrm{~m})$ is a cylinder with a conical base (angle $=60^{\circ}$ ). The liquid solution is pumped into the atomizer by a peristaltic pump (Masterflex 77201, Beligneux, France) with a flow rate in the range of 4 to $280 \mathrm{~mL} \cdot \mathrm{min}^{-1}$. Rotary atomizer speed is controlled by compressed air pressure and it is usually in the range of 25000-30000 rpm. The pressure in the chamber is inferior to the atmospheric pressure, as drying air is sucked by a fan placed at the exit. Air flow rate can be controlled by varying the fan frequency; 


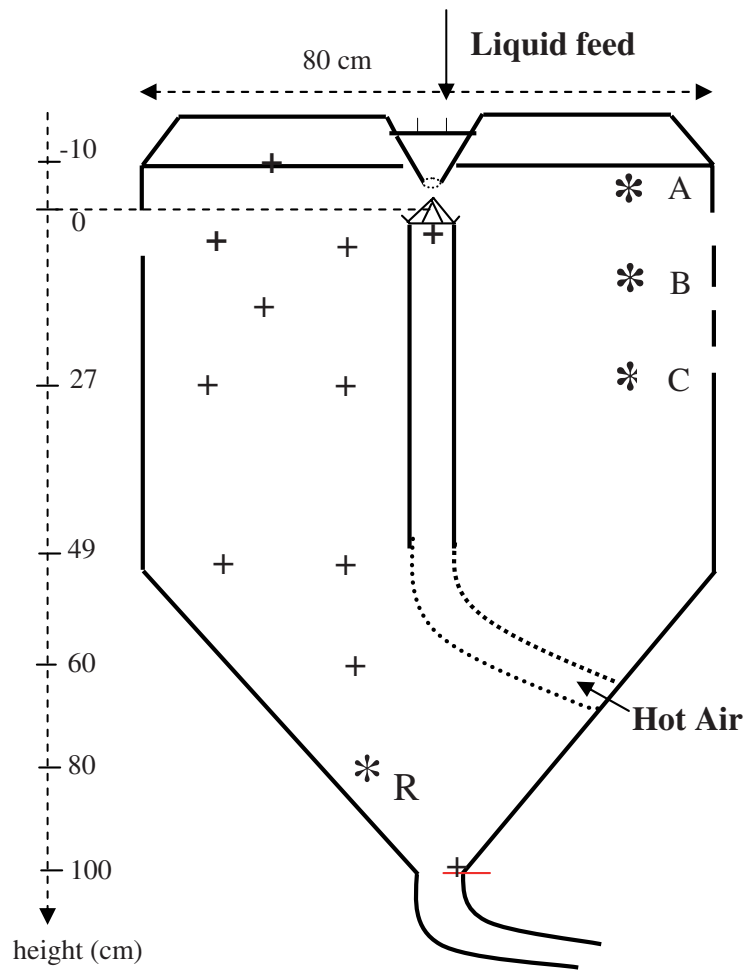

Figure 2. Positions of sensors inside the dryer chamber (+: thermocouples; R: ROTRONIC capacitive hygrometer; * A, B, C: air sampling for dew point hygrometer).

it is measured at the exit using a Pitot tube placed after the fan. Inlet air temperature is controlled using 3 electrical resistances $(0.7-1.5-2 \mathrm{~kW})$ (maximal air temperature $350{ }^{\circ} \mathrm{C}$ ) and it is measured just before dispersion in the chamber (thermocouple). Air enters into the chamber close to the atomizer wheel so that drying is cocurrent. The air disperser imposes an initial horizontal direction then a swirl to the inlet air. Final powder is separated from air within a cyclone, and exhaust air exits to the atmosphere.

The experimental work consisted of obtaining cartographies of air temperature $(\mathrm{T})$ and relative humidity $(\mathrm{RH})$ inside the chamber, at steady state. Air temperatures were measured with 12 thermocouples (K-type) and one platinum probe in the bottom of the drying chamber. Air relative humidity was determined with a capacitive hygrometer (Rotronic, Bassersdorf, Ch $( \pm 1 \% \mathrm{RH}))$ and a dew point hygrometer (General Eastern, Billerica, US) $\left( \pm 0.2{ }^{\circ} \mathrm{C} \rightarrow \pm 0.5 \% \mathrm{RH}\right)$ with air sampling inside the chamber coupled with a thermocouple. Psychrometry was used for inlet and outlet air moisture content. The drying chamber was equipped to allow the placement of all sensors (12 thermocouples and 2 hygrometers) (Fig. 2).

A preliminary step consisted of calibrating the sensors and of their installation inside the chamber. Thermocouples were calibrated at 0 and $100{ }^{\circ} \mathrm{C}$. The capacitive hygrometer was checked in a RH-controlled atmosphere with saturated salt solution at two temperatures 
Table I. Experimental conditions for water and maltodextrin solution spray-drying trials (DE12, $40 \% \mathrm{w} / \mathrm{w}$, air flow rate: $80 \mathrm{~kg} \cdot \mathrm{h}^{-1}$; rotary atomizer speed: $30000 \mathrm{rpm}$ ).

\begin{tabular}{lccc}
\hline Liquid & $\begin{array}{c}\text { Inlet air T } \\
\left({ }^{\circ} \mathrm{C}\right)\end{array}$ & $\begin{array}{c}\text { Liquid flow rate } \\
\left(\mathrm{mL} \cdot \mathrm{min}^{-1}\right)\end{array}$ & $\begin{array}{c}\text { Corresponding water flow rate } \\
\left(\mathrm{mL} \cdot \mathrm{min}^{-1}\right)\end{array}$ \\
\hline Water & $144-159-174$ & $15-18-25-36-54$ & \\
MD solution & $144-159-174$ & $25-50-75$ & $18-36-54$ \\
\hline
\end{tabular}

$\left(\mathrm{NaNO}_{3}: 75 \% \mathrm{RH}\right.$ at $20{ }^{\circ} \mathrm{C} ; 63 \% \mathrm{RH}$ at $80{ }^{\circ} \mathrm{C}$ ). The response time of both hygrometers was evaluated by introducing them inside the spray dryer chamber during a trial of water atomization once the steady state inside the chamber was reached. It was about $10 \mathrm{~min}$ and $3 \mathrm{~min}$ for the capacitive and dew point hygrometers, respectively.

Two sets of spray-drying trials were performed: one by atomizing water and one by atomizing $40 \% \mathrm{w} / \mathrm{w}$ aqueous solutions of maltodextrin DE12 (Glucidex, Roquette, France) as a first model product able to dry and/or stick. Drying parameters were the hot air inlet temperature measured at the air disperser outlet (144-159-174 ${ }^{\circ} \mathrm{C}$ ) and atomized liquid flow rate $\left(15\right.$ to $54 \mathrm{~mL} \cdot \mathrm{min}^{-1}$ for water; and 25 to $75 \mathrm{~mL} \cdot \mathrm{min}^{-1}$ for maltodextrin solution). These flow rates were chosen to compare evaporation in trials with similar water flow rates (Tab. I). Air flow rate $\left(80 \mathrm{~kg} \cdot \mathrm{h}^{-1}\right)$ and rotary atomizer speed (30000 rpm) were kept constant.

Final powder moisture content was measured by oven drying $\left(24 \mathrm{~h}\right.$ at $\left.105^{\circ} \mathrm{C}\right)$.

\section{RESULTS AND DISCUSSION}

\subsection{Spray drying of water}

Spray-drying trials of water showed the feasibility of the air properties measuring approach. Cartographies of air temperature and humidity were obtained after steadystate establishment ( $1 \mathrm{~h})$.

For all tested conditions, air temperature decreased rapidly after the entrance into the chamber (Fig. 3), in the upper part $(\sim 15 \mathrm{~cm})$, close to the atomizer. Below this zone, just a small decrease in air temperature $\left(\Delta \mathrm{T} \leqslant 5^{\circ} \mathrm{C}\right)$ occurred. No radial variation in temperature was observed. For all tested inlet air temperatures the total decrease in temperature through the chamber varied from $50{ }^{\circ} \mathrm{C}$ for the lower liquid flow rate $\left(18 \mathrm{~mL} \cdot \mathrm{min}^{-1}\right)$ to $100{ }^{\circ} \mathrm{C}$ for the higher liquid flow rate $\left(54 \mathrm{~mL} \cdot \mathrm{min}^{-1}\right)$. For water flow rates between 15 and $54 \mathrm{~mL} \cdot \mathrm{min}^{-1}$, the temperature values inside the chamber were in the range $120-70{ }^{\circ} \mathrm{C}$ for inlet air at $174{ }^{\circ} \mathrm{C}, 110-60{ }^{\circ} \mathrm{C}$ for inlet air at $159{ }^{\circ} \mathrm{C}$ and $100-50{ }^{\circ} \mathrm{C}$ for inlet air at $144^{\circ} \mathrm{C}$.

The air water content, Y ( $\mathrm{kg}$ water $/ \mathrm{kg}$ dry air), increased rapidly in the upper part of the chamber (Fig. 4) where the high decrease in temperature was observed. For $174{ }^{\circ} \mathrm{C}$, a mass balance $\dot{m}_{\text {evaporated Water }}=$ $\left.\dot{m}_{\text {dryAir }}{ }^{*}\left(Y_{\text {air }}-Y_{\text {airIN }}\right)\right]$ showed that all the water $(99 \%)$ was evaporated in the upper part of the spray dryer $(\sim 15 \mathrm{~cm})$ for the three liquid flow rates, and the air water content did not change in the lower part of the chamber. For air temperature at $144{ }^{\circ} \mathrm{C}$, 65 to $89 \%$ of the water was evaporated in the first part of the chamber, depending on the liquid flow rate, but drying was not completed and air water content still increased along the chamber. In the bottom part of the dryer $(80 \mathrm{~cm})$ water evaporation varied from 92 to $100 \%$. As for temperature, no radial variation in air water content was observed. For the lower liquid flow rate of $18 \mathrm{~mL} \cdot \mathrm{min}^{-1}$, calculation of evaporated water showed that, compared with the other liquid flow rates, a smaller fraction of water was evaporated in the top of the chamber. That could be explained by 

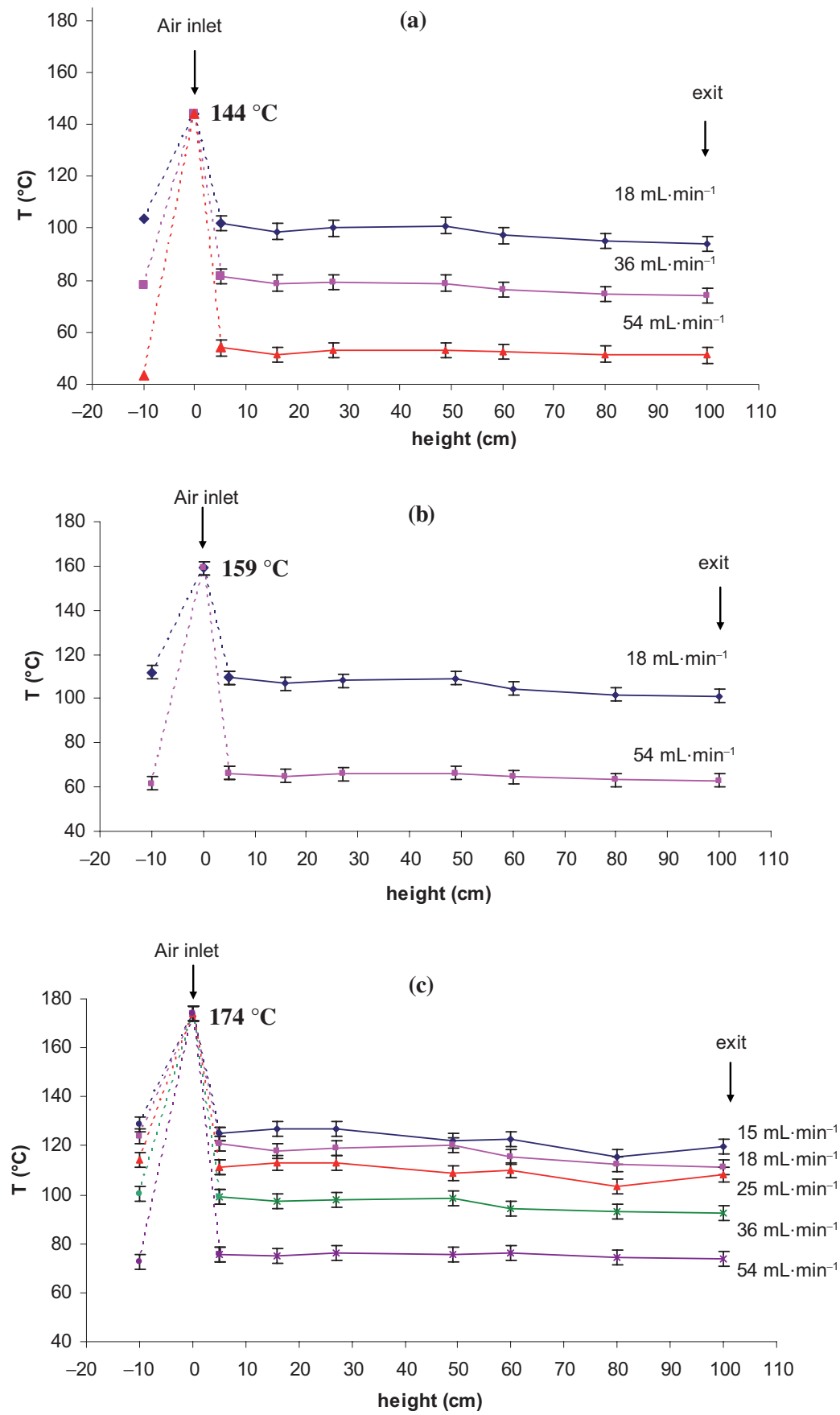

Figure 3. Water spray drying: air temperature inside the drying chamber at different positions for 3 inlet air temperatures ((a) $144{ }^{\circ} \mathrm{C}$, (b) $159^{\circ} \mathrm{C}$, (c) $\left.174{ }^{\circ} \mathrm{C}\right)$. 

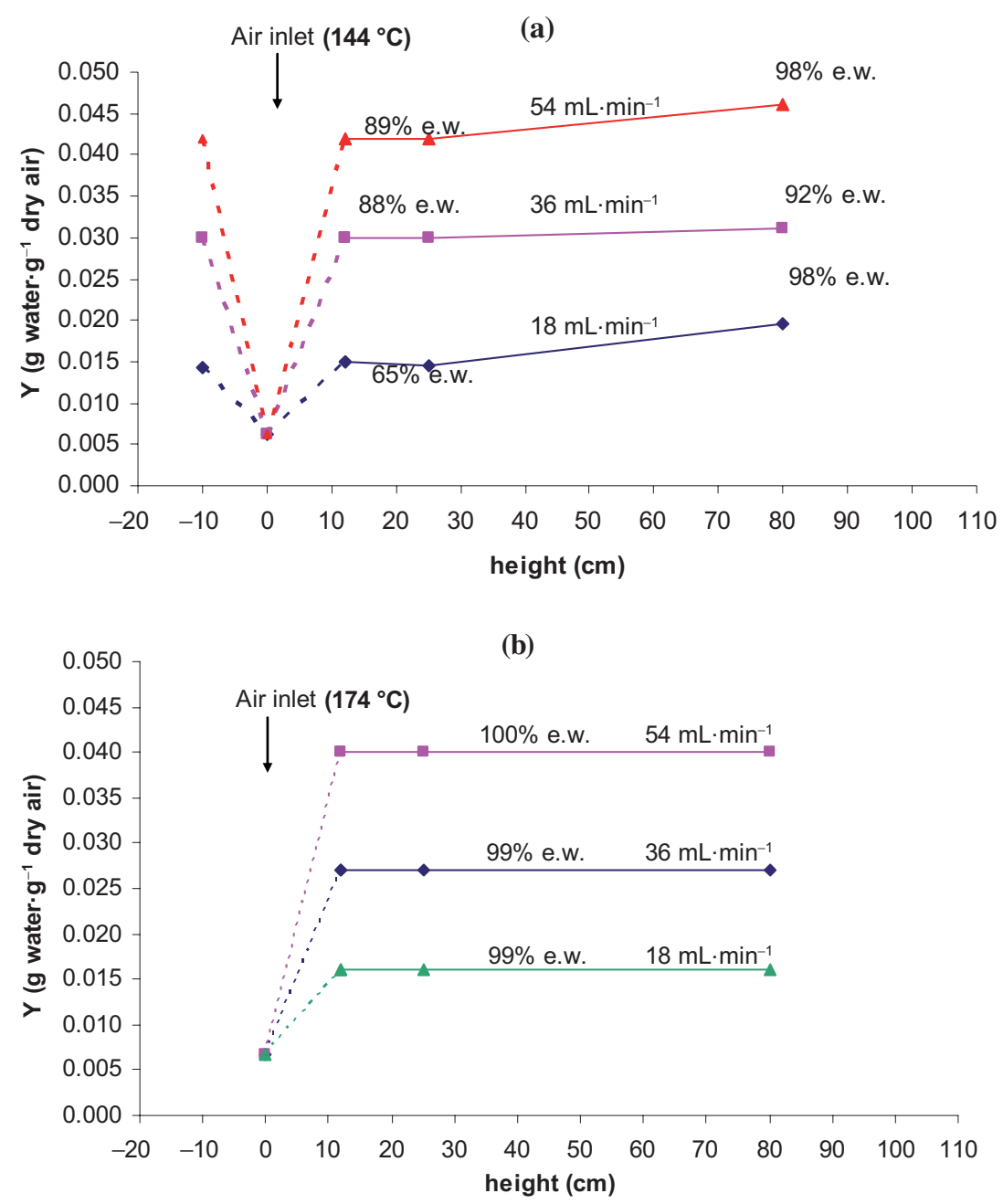

Figure 4. Water spray drying: air water content inside the drying chamber at different positions for 2 inlet air temperatures ((a) $144{ }^{\circ} \mathrm{C}$, (b) $174{ }^{\circ} \mathrm{C}$; e.w.: evaporated water).

the accuracy of humidity measurements inside the chamber, especially for low relative humidity ( $2 \%)$; in this case, a $0.5 \%$ error in RH measurement could lead to a $25 \%$ difference in calculation of evaporated water.

To perform maltodextrin solution trials, we looked for water drying conditions for which drying was not completed. Conditions for which exit air temperature is low and relative humidity is high could lead to difficult drying of a real product solution. The biggest variations between inlet and exit air properties with the different tested water flow rates were found for an inlet air temperature of $144{ }^{\circ} \mathrm{C}$ (Tab. II). In that case, for a liquid flow rate of $18 \mathrm{~mL} \cdot \mathrm{min}^{-1}$, exit air was at $95{ }^{\circ} \mathrm{C}$ with $3 \%$ relative humidity: these conditions, far from saturated air, should lead to good drying. For a liquid 
Table II. Air properties during spray drying of water (IN: inlet; OUT: outlet; RH: relative humidity; T: temperature; R: measured with Rotronic).

\begin{tabular}{lcccccccccc}
\hline Inlet air T $\left({ }^{\circ} \mathrm{C}\right)$ & \multicolumn{1}{c}{144} & \multicolumn{1}{c}{159} & \multicolumn{7}{c}{174} \\
\hline Water flow rate & & & & & & & & & & \\
$\left(\mathrm{mL} \cdot \mathrm{min}^{-1}\right)$ & 18 & 36 & 54 & 18 & 54 & 15 & 18 & 25 & 36 & 54 \\
Exit air T $\left({ }^{\circ} \mathrm{C}\right)(\mathrm{R})$ & 96 & 75 & 51 & 103 & 63 & 121 & 114 & 109 & 94 & 73 \\
$\Delta \mathrm{T}$ air IN - OUT & 49 & 70 & 93 & 56 & 96 & 53 & 60 & 66 & 80 & 101 \\
Exit air RH $(\mathrm{R})(\%)$ & 3.54 & 12.2 & 53.2 & 2.9 & 30.5 & 1.93 & 2.3 & 3.32 & 5.6 & 22.3 \\
\hline
\end{tabular}

flow rate of $54 \mathrm{~mL} \cdot \mathrm{min}^{-1}$, exit air temperature was at $50{ }^{\circ} \mathrm{C}$ with $50 \%$ relative humidity: drying problems could occur. Consequently, we focused on the $144{ }^{\circ} \mathrm{C}$ inlet air temperature for spray drying of maltodextrin aqueous solution, with the various liquid flow rates to get different drying conditions.

\subsection{Spray drying of maltodextrin aqueous solution}

Maltodextrin aqueous solution (40\% $\mathrm{w} / \mathrm{w})$ trials were compared with pure water trials at $144{ }^{\circ} \mathrm{C}$, using liquid flow rates corresponding to the same amount of water to evaporate, so that the drying behavior could be compared.

For a low liquid flow rate $\left(25 \mathrm{~mL} \cdot \mathrm{min}^{-1}\right.$, corresponding to $18 \mathrm{~mL} \cdot \mathrm{min}^{-1}$ of water to evaporate), values of air temperature and humidity were close to the values obtained for water drying (Figs. 5a and 5b). With a mass balance, we showed that during maltodextrin solution drying $57 \%$ of the water was evaporated close to the atomizer compared to $65 \%$ for water drying trials. Almost all water was evaporated at the exit of the chamber $(98 \%)$ both for water and maltodextrin solution spray drying. When increasing the liquid flow rate, differences in drying behavior were observed (Figs. 5c and 5d). For a high liquid flow rate $\left(75 \mathrm{~mL} \cdot \mathrm{min}^{-1}\right.$, corresponding to $54 \mathrm{~mL} \cdot \mathrm{min}^{-1}$ of water to evaporate) air temperature inside the chamber was some 10 degrees higher than in the water drying trials, and drying was not completed even at the exit of the chamber, with only $81 \%$ of water evaporated in the bottom part compared with $98 \%$ for water drying.

Air water content evolution inside the chamber during spray drying of water and of maltodextrin solution (Figs. 4 and 6) showed that for any liquid flow rate the amount of evaporated water was lower in the case of maltodextrin solution drying at any level in the chamber. This tendency was observed even for the low liquid flow rate trials where the relative humidity measured was low (poor precision). During water spray drying, all the water was evaporated at the exit for all liquid flow rates. But during maltodextrin spray drying it was almost completed in the chamber $(98 \%$ water evaporated) only for the lowest solution flow rate $\left(25 \mathrm{~mL} \cdot \mathrm{min}^{-1}\right)$. Higher solution flow rates led to incomplete drying (80 to $88 \%$ of water evaporated), showing that the drying rate of a solution is lower than that of water. In the maltodextrin solution, water is bound to the solute (maltodextrin), and drying is also limited by the water diffusion rate from the drop core to the surface. Heat and mass transfers between the drop surface and air depend on temperature and vapor pressure gradients between the two phases. When the surface water activity decreases (water bound to the solute, diffusion) the water vapor pressure at the surface of the drying drop is lower than that of free water. The vapor pressure gradient between drying air and the drop surface is lower and the exchange 

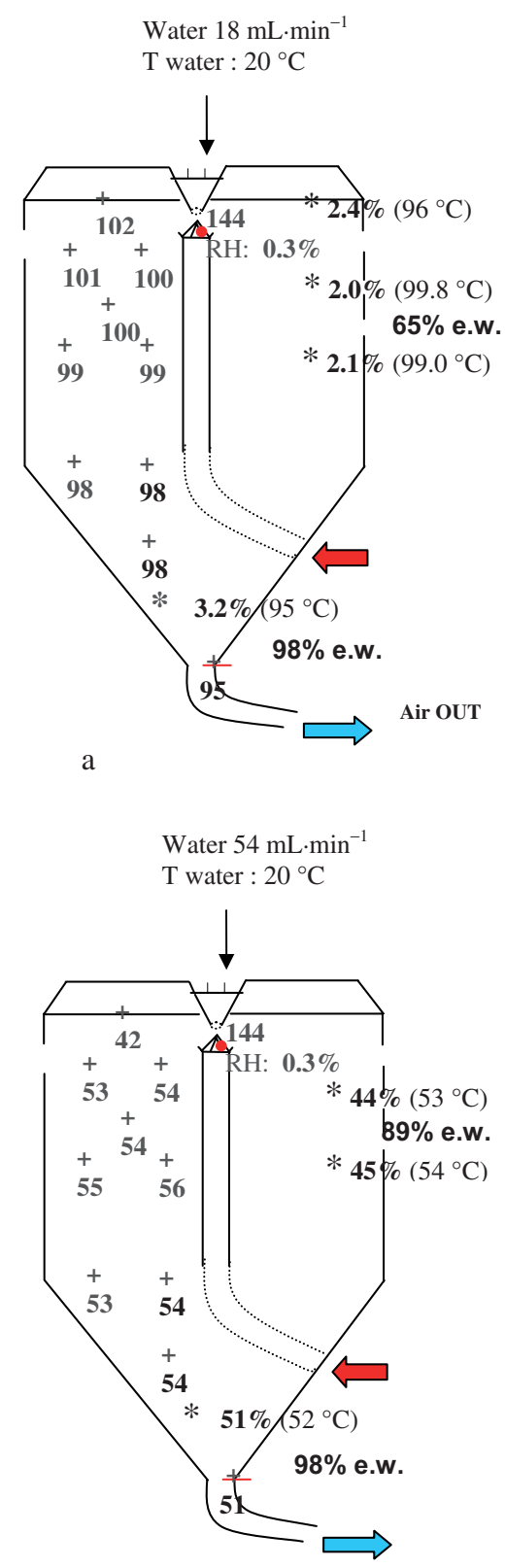

$\mathrm{c}$
$40 \% \mathrm{w} / \mathrm{w}$ MD12 solution
$25 \mathrm{~mL} \cdot \mathrm{min}^{-1}\left(\rightarrow 18 \mathrm{~mL} \cdot \mathrm{min}^{-1}\right.$ water to evaporate $)$

T solution : $20{ }^{\circ} \mathrm{C}$

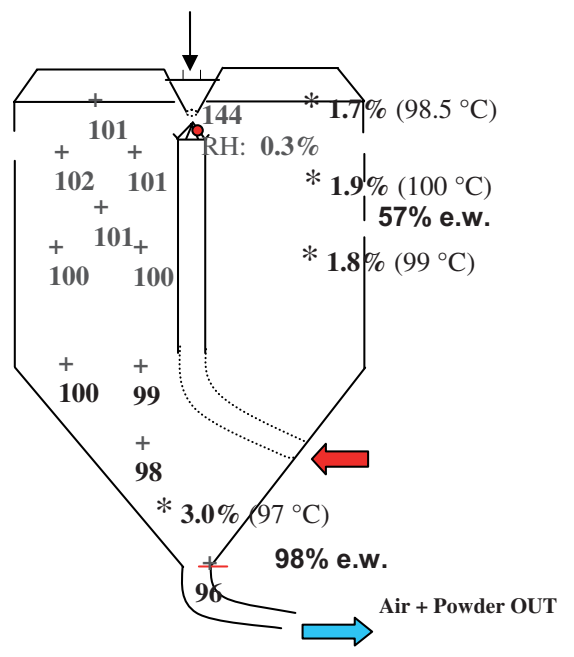

b

$40 \%$ w/w MD12 solution

$75 \mathrm{~mL} \cdot \mathrm{min}^{-1}\left(\rightarrow 54 \mathrm{~mL} \cdot \mathrm{min}^{-1}\right.$ water to evaporate)

T solution : $20^{\circ} \mathrm{C}$

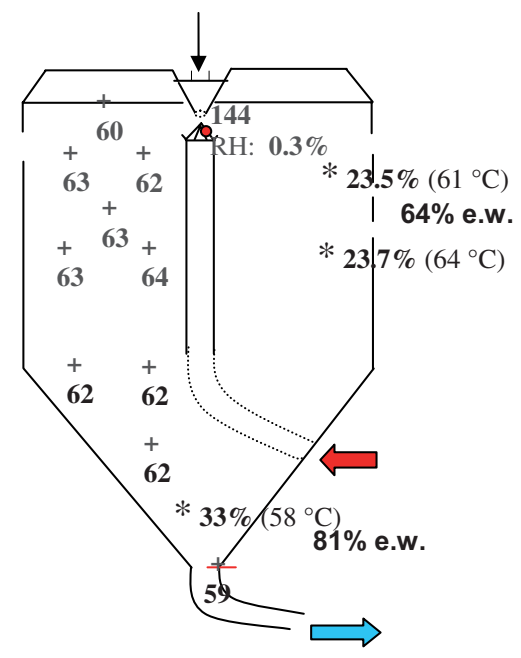

d

Figure 5. Air temperature and relative humidity inside the drying chamber during drying of pure water $(\mathrm{a}, \mathrm{c})$ and maltodextrin solution $(\mathrm{b}, \mathrm{d})$, with the same amount of water to evaporate, $18 \mathrm{~mL} \cdot \mathrm{min}^{-1}(\mathrm{a}, \mathrm{b})$ and $54 \mathrm{~mL} \cdot \mathrm{min}^{-1}(\mathrm{c}, \mathrm{d})$.

$\left(+\right.$ : temperature $\left({ }^{\circ} \mathrm{C}\right)$; *: relative humidity (temperature) $\%\left({ }^{\circ} \mathrm{C}\right)$; e.w.: evaporated water; inlet air $144{ }^{\circ} \mathrm{C}, 80 \mathrm{~kg} \cdot \mathrm{h}^{-1}$.) 


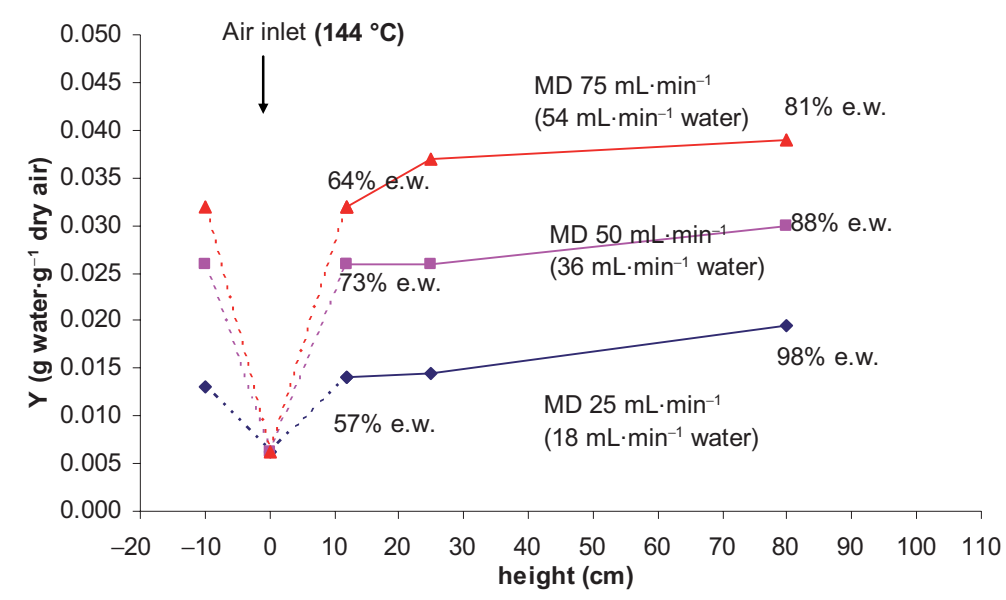

Figure 6. Maltodextrin solution spray drying: air water content inside the drying chamber at different positions.

(Solution MD DE12, 40\% w/w; inlet air temperature: $144{ }^{\circ} \mathrm{C}$; e.w.: evaporated water).

rate of water decreases. For a low liquid flow rate, air temperature inside the chamber is high $\left(100^{\circ} \mathrm{C}\right)$ and the air is far from saturation ( $2.0 \%$ relative humidity); in this case, heat and mass transfers are good and drying can be completed inside the chamber. Higher liquid flow rates (50 and $75 \mathrm{~mL} \cdot \mathrm{min}^{-1}$ ) lead to lower air temperatures (respectively, 75 and $65^{\circ} \mathrm{C}$ ) with higher relative humidity (11 and 30\%); as a consequence, heat and mass transfers are slowed down and drying is not completed inside the chamber, probably due to the short residence time.

Data on air water content allow the estimation of drop/particle average water content during drying from a mass balance of evaporated water. Estimations of particle water content in the conical part of the chamber (Tab. III) showed that for the low solution flow rate $\left(25 \mathrm{~mL} \cdot \mathrm{min}^{-1}\right)$ drying is completed inside the chamber and the water content of the final powder is the same as that calculated in the conical part (3 g water $100 \mathrm{~g}^{-1}$ dry matter). For higher solution flow rates, particles in the conical part still contain more than $20 \mathrm{~g}$ water $100 \mathrm{~g}^{-1}$ dry matter (calculation) and the final collected powders still contain more than $5 \mathrm{~g}$ water $100 \mathrm{~g}^{-1}$ dry matter. The measurement of air temperature and humidity in the bottom part of the chamber could therefore be used as an inline indirect method to estimate if drying conditions allow to obtain a dry product within specifications. As expected from the water drying trials, the experiment with a low air inlet temperature $\left(144{ }^{\circ} \mathrm{C}\right)$ and a high liquid flow rate $\left(75 \mathrm{~mL} \cdot \mathrm{min}^{-1}\right)$ led to a final powder that still had a high moisture content $(>8 \%)$. During the trial, some powder adhesion on the walls of the chamber was observed with losses of product. These conditions, corresponding to stickiness of drying particles, could be considered to perform agglomeration by introduction of fines inside the chamber, while avoiding sticking on chamber walls.

\section{CONCLUSION}

An experimental approach to measure air temperature and relative humidity inside the spray dryer chamber was tested and validated during drying of water and of 
Table III. Powder average water content calculated in the conical part of the chamber (R) and measured on the final powder (maltodextrin solution $40 \% \mathrm{w} / \mathrm{w}, 20{ }^{\circ} \mathrm{C}$, inlet air T $144{ }^{\circ} \mathrm{C}$ ).

\begin{tabular}{lccc}
\hline $\begin{array}{l}\text { Liquid flow rate } \\
\left(\mathrm{mL} \cdot \mathrm{min}^{-1}\right)\end{array}$ & Initial solution & $\mathrm{R}($ calculated $)$ & Final powder (measured) \\
\hline 25 & 150 & 3.0 & 3.0 \\
50 & 150 & 18.0 & 5.0 \\
75 & 150 & 29.0 & 8.5 \\
\hline
\end{tabular}

an aqueous solution of maltodextrin $(40 \%$ $\mathrm{w} / \mathrm{w}$ ) for different drying parameters (inlet air temperature $144-159-174{ }^{\circ} \mathrm{C}$; liquid flow rates from 15 to $75 \mathrm{~mL} \cdot \mathrm{min}^{-1}$ ). This approach was applied to obtain cartographies in another pilot equipment with success.

In this study, for all tested conditions, most of the drying occurred in the region close to the atomizer. The drying behavior of maltodextrin solution appeared to be different from that of pure water (slower water evaporation), the difference being significant when increasing the liquid flow rate. For the higher solution flow rates, drying was not completed at the exit of the chamber, leading to still humid final powder with product losses due to sticking on the walls.

Knowledge of air properties evolution during drying may allow the estimation of drop/particle properties (temperature and average water content) that could then be related to the stickiness of the considered substance, in particular with glass transition.

The further steps of the work will consist of introducing various fine particles in defined locations inside the chamber, varying the drying parameters, to study the feasibility of agglomeration and the effect of parameters on final product properties at different scales (pilot, semi-industrial and industrial). These experimental data and Computational Fluid Dynamics (CFD) technology will also be used to simulate the drying and agglomeration processes.
Acknowledgements: This work was financially supported by the EU 6th Framework program through the Marie Curie Research Training Network Biopowders (MRTN-CT2004-512247).

\section{REFERENCES}

[1] Boonyai P., Bhandari B.R., Howes T., Development of a novel testing device to characterize the sticky behaviour of food powders - a preliminary study, in: International Conference on Innovations in Food Processing and Technology and Engineering, 11-13 December 2002, Bangkok, Thailand.

[2] Boonyai P., Bhandari B.R., Howes T., Stickiness measurement techniques for food powders: a review, Powder Technol. 145 (2004) 34-46.

[3] Dixon A., Bloore C., Correlating food powder stickiness with composition, temperature, and relative humidity, Research report, Monash University, Melbourne, AU, 1999.

[4] Hennigs C., Kockel T.K., Langrish T.A.G., New measurements of the sticky behaviour of skim milk powder, Drying Technol. 19 (2001) 471-484.

[5] Huntington D.H., The influence of the spray drying process on product properties, Drying Technol. 22 (2004) 1261-1287.

[6] Kudra T., Sticky region in drying-definition and identification, in: The International Conference on Energy-Saving Technologies for Drying and Hygrothermal Processing, 28-31 May 2002, Moscow, Russia.

[7] Labuza T.P., Sorption phenomena in foods, Food Technol. 22 (1968) 263.

[8] Lazar M.E., Brown A.H., Smith G.S., Wong F.F., Lindquist F.E., Experimental production of tomato powder by spray drying, Food Technol. 10 (1956) 129-134.

[9] Lockemann C.A., A new laboratory method to characterize the sticking property of 
free flowing solids, Chem. Eng. Process 38 (1999) 301-306. Badly placed ()'s.

[10] Ozkan N., Walisinghe N., Dong Chen X., Characterization of stickiness and cake formation in whole and skim milk powders, J. Food Eng. 55 (2002) 293-303.

[11] Palzer S., The effect of glass transition on the desired and undesired agglomeration of amorphous food powders, Chem. Eng. Sci. 60 (2005) 3959-3968.

[12] Pisecky J., Handbook of Milk Powder Manufacture, Copenaghen, Denmark, NIRO A/S, 1997.

[13] Roos Y.H., Karel M., Applying state diagrams to food processing and development, Food Technol. 45 (1991) 66-107.
[14] Roos Y.H., Karel M., Water and molecular weight effects on glass transition in amorphous carbohydrates and carbohydrate solutions, J. Food Sci. 56 (1991) 1676-1681.

[15] Tsourouflis S., Flink J.M., Karel M., Loss of structure in freeze dried carbohydrate solutions. Effect of temperature, moisture contents and compositions, J. Sci. Food Agric. 27 (1976) 509-519.

[16] Werner S.R.L., Jones J.R., Paterson A.H.J., Stickiness of maltodextrins using probe tack test during in-situ drying, J. Food Eng. 80 (2007) 859-868.

[17] Zbicinski I., Piatkowski M., Spray drying tower experiments, Drying Technol. 22 (2004) 1325-1349. 